\title{
Multiyear Typology of Long-Range Transported Aerosols over Europe
}

\author{
Victor Nicolae 1,2, Camelia Talianu 1,3, Simona Andrei ${ }^{1}$, Bogdan Antonescu ${ }^{1,2}$, Dragos, Ene ${ }^{1}$ (1), \\ Doina Nicolae ${ }^{1}$, Alexandru Dandocsi ${ }^{1,4}$, Victorin-Emilian Toader ${ }^{5}$, Sabina Ștefan ${ }^{2}$, \\ Tom Savu ${ }^{6}$ and Jeni Vasilescu ${ }^{1, *}$ (D) \\ 1 National Institute of Research and Development for Optoelectronics INOE2000, Atomistilor 409, RO77125 \\ Magurele, Romania \\ 2 Faculty of Physics, University of Bucharest, Atomistilor 405, RO77125 Magurele, Romania \\ 3 Institute of Meteorology and Climatology, University of Natural Resources and Life Sciences, 1180 Vienna, \\ Austria \\ 4 Faculty of Applied Sciences, Politehnica University of Bucharest, Splaiul Independentei 313, RO060042 \\ Bucuresti, Romania \\ 5 National Institute for Earth Physics, Calugareni 12, RO077125 Magurele, Romania \\ 6 DOLSAT Consult, Al. Valea lui Mihai 2, sector 6, RO061756 București, Romania \\ * Correspondence: jeni@inoe.ro
}

Received: 16 July 2019; Accepted: 16 August 2019; Published: 22 August 2019

\begin{abstract}
In this study, AERONET (Aerosol Robotic Network) and EARLINET (European Aerosol Research Lidar Network) data from 17 collocated lidar and sun photometer stations were used to characterize the optical properties of aerosol and their types for the 2008-2018 period in various regions of Europe. The analysis was done on six cluster domains defined using circulation types around each station and their common circulation features. As concluded from the lidar photometer measurements, the typical aerosol particles observed during 2008-2018 over Europe were medium-sized, medium absorbing particles with low spectral dependence. The highest mean values for the lidar ratio at $532 \mathrm{~nm}$ were recorded over Northeastern Europe and were associated with Smoke particles, while the lowest mean values for the Angstrom exponent were identified over the Southwest cluster and were associated with Dust and Marine particles. Smoke (37\%) and Continental (25\%) aerosol types were the predominant aerosol types in Europe, followed by Continental Polluted (17\%), Dust (10\%), and Marine/Cloud (10\%) types. The seasonal variability was insignificant at the continental scale, showing a small increase in the percentage of Smoke during spring and a small increase of Dust during autumn. The aerosol optical depth (AOD) slightly decreased with time, while the Angstrom exponent oscillated between "hot and smoky" years (2011-2015) on the one hand and "dusty" years (2008-2010) and "wet" years (2017-2018) on the other hand. The high variability from year to year showed that aerosol transport in the troposphere became more and more important in the overall balance of the columnar aerosol load.
\end{abstract}

Keywords: aerosol typing; lidar; photometry; EARLINET; AERONET

\section{Introduction}

Aerosols influence the planetary radiation budget in both direct and indirect ways by absorbing and scattering solar radiation or by changing cloud properties [1]. Knowledge of aerosol physical and chemical properties can increase our current level of understanding of aerosol effects, variability, and their emerging role in climate change. Global and regional datasets of aerosol properties can be obtained from satellite or ground-based measurements (e.g., References [2,3]). Satellite data give good 
spatial coverage but suffer from poor temporal coverage; however, this is currently compensated for by synergistic approaches using ground-based measurements. Continental ground-based networks such as the European Aerosol Research Lidar Network (EARLINET, https://www.earlinet.org) and global networks such as the Aerosol Robotic Network (AERONET, https://aeronet.gsfc.nasa.gov/) have measured aerosol properties for more than two decades, building on data quality through their complex quality assurance programs. These long-term databases give the opportunity to assess the main properties of aerosol types, their variability at least on a continental scale, the processes driving property changes, long-range transport, or seasonal occurrence (e.g., References [3,4]). Recently, the two networks have joined their efforts in the frame of the Aerosols, Clouds, and Trace gases Research InfraStructure (ACTRIS, https://www.actris.eu/, [5,6]).

Raman lidar systems are the basic instruments used on regular bases in EARLINET. The continental scale coverage and simultaneous measurements schedule give the opportunity to study aerosol properties using vertically resolved data $[5,7,8]$. Lidar systems can provide information regarding the aerosol content on multiple layers due to their temporal and vertical high resolution. A distinct classification of the predominant aerosol on each layer is thus possible when using the intensive lidar parameters, which can be retrieved when following the usual practice within the EARLINET community. The classification includes layer boundaries identification and the calculation of intensive optical property values (i.e., lidar ratios, Angstrom exponents, particle linear depolarization ratios) specific to the layer and evaluation, taking into account other instruments or model outputs $[9,10]$. This subjective approach is highly time-consuming, and a subjective mode to derive the aerosol types is usually conducted only for special cases.

AERONET is a global network formed by ground-based sun-sky or lunar photometers and was established more than 25 years ago by NASA (National Aeronautics and Space Administration, i.e., globally) and PHOTONS (PHOtométrie pour le Traitement Opérationnel de Normalisation Satellitaire, i.e., for Europe) [11,12]. Long-term optical, microphysical, and radiative columnar aerosol properties are retrieved in a standardized and controlled mode. Evaluation and classification of aerosols are possible using the key parameters retrieved from photometer data. Aerosol optical properties from AERONET data are also used on different classification methods to determine the predominant aerosol type $[13,14]$. Biomass burning or desert dust aerosols are some of the classes that can be identified due to their distinct optical parameters [15,16]. The extinction Angstrom exponent (AE) 380/500 nm values near unit are assumed to be characteristic for industrial aerosols, while there are smaller values for dust types and larger values for biomass burning aerosols [16]. Similarly, the high values of aerosol optical depth (AOD) at $500 \mathrm{~nm}$ correspond to biomass burning events, while near zero represents the background level [17].

The aerosol mixtures are difficult to assess from sun photometers or lidar retrievals because different aerosol types have overlapping characteristic parameters. The combination of collocated lidar and photometer data give the opportunity to better assess aerosol types. The parameters used to identify the aerosol types are often a combination of lidar ratios (LRs), particle depolarization ratios (PDRs), AEs, and AODs [8,18,19].

The accuracy of aerosol classification is low using a subjective approach due to both multiple mandatory assumptions and similar properties of different aerosol types. Most of the typing methods are focused on advanced lidar systems, such as high spectral resolution lidar [7] or multiwavelength Raman measurements [8], sometimes also including particle linear depolarization. More automatic approaches have been explored in recent studies dedicated to aerosol typing using optical parameters retrieved from ground-based or satellite lidar measurements $[5,7,9,19,20]$.

In this study, both AERONET and EARLINET data were used to characterize the optical properties of aerosol for the 2008-2018 period in various regions of Europe. For EARLINET data, an artificial neural network (ANN) software developed by Nicolae D. et al. [20] was used to derive the predominant type of aerosol. The ANN tends to simulate the human neural network comportment, learning after multiple similar situations and being able to choose between comparable inputs. ANNs are widely 
used in data processing or classification, including applications in atmospheric sciences, due to their capacity to deal with noisy data and superposed clusters. The ANN capacity to deal with nonlinear relationships between data is exploited in lidar data processing [21], improvements in satellite data related to aerosol properties [22], and retrieval of atmospheric temperature profiles from satellite measurements [23].

The aim of this article is to provide for the first time, to the authors' knowledge, a multiyear typology of long-range transported aerosols over Europe. The analysis was made on the basis of lidar data from EARLINET and collocated sun photometer data from AERONET. The article is structured as follows: Section 2 describes the observational data used to do the aerosol typing over Europe, a neural network aerosol typing algorithm based on lidar data, and the defined regions based on typical air mass transport. Optical characteristics of aerosols and aerosol types over Europe are discussed in Section 3. Section 4 summarizes the concluding remarks.

\section{Data and Methodology}

To analyze the optical characteristics of the aerosols and their type, a combined set of collocated lidar and sun photometer data was used. Optical properties of aerosols were retrieved from lidar and separately from sun photometers and then compared. A neural network aerosol typing algorithm based on lidar data (NATALI) software, already tested on synthetic data and a small set of measured data [20], was used to classify aerosols using lidar data from EARLINET stations.

\subsection{Observational Data}

The EARLINET database (i.e., multispectral Raman lidar climatological data available from [24]) and the AERONET database (i.e., sun/sky photometer measurements available from [25]) were the two main data sources used in this article to obtain a multiyear typology of long-range transported aerosols over Europe between 2008 and 2018. Geographically distributed stations that operated both multiwavelength Raman lidars and automatic sun/sky photometers were selected, considering the availability of long-term records from both instruments (Figure 1 and Table 1).

The EARLINET climatological measurements were systematically performed every Monday at (locally) noon and every Monday and Thursday evening after local sunset. The measurements were performed for at least $2 \mathrm{~h}$ at the wavelengths $355 \mathrm{~nm}, 532 \mathrm{~nm}$, and $1064 \mathrm{~nm}$ for the elastic channels, 387 $\mathrm{nm}$ and $607 \mathrm{~nm}$ for the Raman channels, and $532 \mathrm{~nm}$ for the depolarization channel. In order to assess the quality of the measurements, EARLINET developed a specific quality assurance program, which is mandatory for all lidar stations [5]. This program is improved year by year and is currently being developed by the Centre for Aerosol Remote Sensing in ACTRIS.

Combined method [26] and inversion algorithms [27,28] were applied to lidar measurements to retrieve the vertical profiles of the aerosol backscatter coefficient at $355 \mathrm{~nm}, 532 \mathrm{~nm}$, and $1064 \mathrm{~nm}$, and the aerosol extinction coefficient at $355 \mathrm{~nm}$ and $532 \mathrm{~nm}$. The calibrated depolarization vertical profiles of the aerosols were computed using the method proposed by Freudenthaler [29] and Belegante et al. [30]. The inversion of lidar measurements to retrieve the aerosol backscatter and extinction coefficient profiles and their associated uncertainties was done for many years at the level of each lidar station using its own software (therefore an important vulnerability for the network). Only recently, EARLINET developed the single calculus chain (SCC) [31], a centralized software to process lidar data from all stations in a homogeneous and quality assured manner. However, the data presented in this paper were not processed with the SCC, which was not available at the time the measurements were done. Due to the small number of calibrated depolarization datasets, they were also not used.

Starting from the aerosol extensive properties (backscatter and extinction coefficient profiles), all subsequent analysis was made using the NATALI software [20]. Lidar datasets collected between 2008 and 2018 by 17 stations of EARLINET distributed over all of Europe (Figure 1) were used as input. The aerosol layers were identified from the lidar measurements with the gradient method based on the identification of the peaks and valleys from the first derivative applied to the vertical 
profiles of backscatter coefficients at $1064 \mathrm{~nm}$. Multiple criteria regarding the quality assurance (QA) of lidar data were used to make the aerosol typing as accurate as possible. The NATALI software performs aerosol typing only if all aerosol intensive optical parameters are provided and their values are between the thresholds that are defined based on previous studies [20]. The typing process is done for layers that pass these criteria, and otherwise the probability of misclassifying or returning an unknown type increases. In addition, a flag stating that typing is uncertain appears when the relative error of any of the intensive optical parameters is higher than 20\%. Besides these QA criteria already implemented in the NATALI software, an extra filter was applied to the EARLINET climatological datasets. Only intensive optical parameter sets that corresponded to possible physical characteristics of aerosols were retained for aerosol typing. Thus, aerosol layers characterized by small particles with low absorbance or by big particles and high absorbance were considered physically highly improbable and were removed from the typing datasets. After all QA criteria were applied to the total number of 4957 layers from lidar, only 808 were selected for aerosol typing ( 16\%) (Table 1).

The AERONET photometer measurements of the solar and sky radiance were performed automatically at $340 \mathrm{~nm}, 380 \mathrm{~nm}, 440 \mathrm{~nm}, 500 \mathrm{~nm}, 670 \mathrm{~nm}, 870 \mathrm{~nm}$, and $1020 \mathrm{~nm}$. The columnar optical properties (i.e., aerosol optical depth, Angstrom exponent, single scattering albedo, phase functions, and asymmetry parameters) were computed using the AERONET inversion algorithm [32,33]. From the AERONET products, the monthly mean values of the AE at $380 \mathrm{~nm}$ and $500 \mathrm{~nm}$ and the AOD at $500 \mathrm{~nm}$ were selected for analysis. Standard deviation was used as a measure of variability of these parameters. For those stations where the 500-nm wavelength was not available, the AOD at $500 \mathrm{~nm}$ was calculated from the AOD at $440 \mathrm{~nm}$ and AE using equations from Soni et al. [34].

Annual and seasonal mean values of aerosol intensive optical parameters were calculated for the overall datasets or on each defined geographical cluster. Observing stations and the number of datasets considered in this study are presented in Table 1.

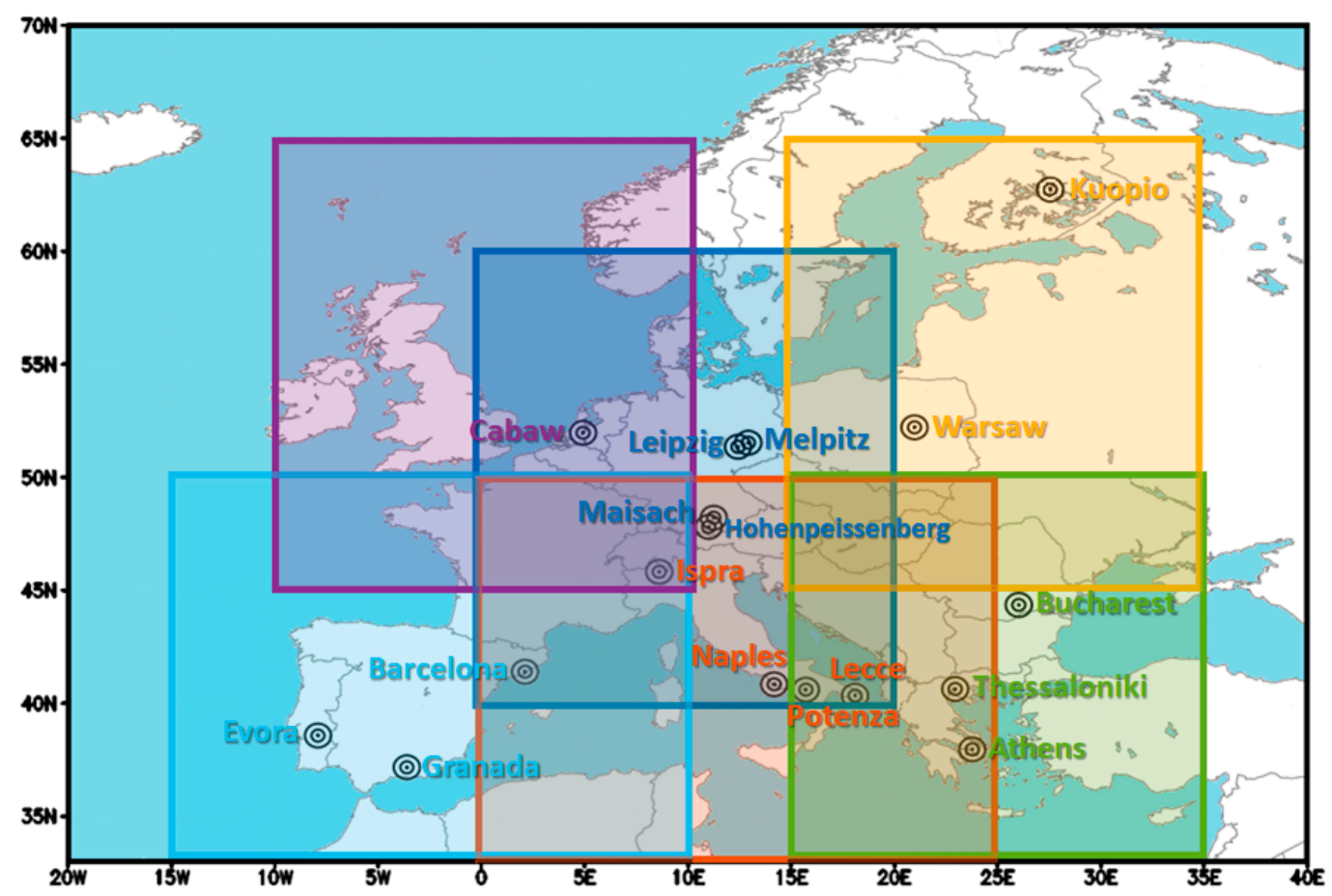

Figure 1. Cluster domains: Central (in blue, containing Hohenspeissenberg, Leipzig, Maisach, and Melpitz), Southeast (in green, containing Athens, Bucharest, and Thessaloniki), Mediterranean (in orange, containing Ispra, Lecce, Naples, and Potenza), Southwest (in cyan, containing Barcelona, Evora, and Granada), Northwest (in magenta, containing Cabaw), and Northeast (in yellow, containing Kuopio and Warsaw). 
Table 1. List of observing stations and number of data points used (2008-2018). QA: quality assurance.

\begin{tabular}{cccccccc}
\hline Station & $\begin{array}{c}\text { Longitude } \\
\text { (E) }\end{array}$ & $\begin{array}{c}\text { Latitude } \\
\mathbf{( N )}\end{array}$ & $\begin{array}{c}\text { Altitude } \\
\text { (m a.s.1.) }\end{array}$ & $\begin{array}{c}\text { Number of Data } \\
\text { Points from } \\
\text { Photometer } \\
\text { (Monthly Means) }\end{array}$ & $\begin{array}{c}\text { Number } \\
\text { of Profiles } \\
\text { from } \\
\text { Lidar }\end{array}$ & $\begin{array}{c}\text { Number } \\
\text { of Layers } \\
\text { from } \\
\text { Lidar }\end{array}$ & $\begin{array}{c}\text { Number of } \\
\text { QA Layers } \\
\text { from Lidar }\end{array}$ \\
\hline Athens & 23.78 & 37.96 & 212 & 128 & 63 & 302 & 37 \\
Barcelona & 2.12 & 41.393 & 115 & 132 & 2 & 9 & 2 \\
Bucharest & 26.029 & 44.348 & 93 & 132 & 227 & 880 & 126 \\
Cabaw & 4.93 & 51.97 & 0 & 132 & 37 & 213 & 26 \\
Evora & -7.9115 & 38.5678 & 293 & 132 & 205 & 851 & 101 \\
Granada & -3.605 & 37.164 & 680 & 132 & 120 & 679 & 106 \\
Hohenpeissenberg & 11.0119 & 47.8019 & 974 & 69 & 33 & 157 & 17 \\
Ispra & 8.6167 & 45.8167 & 209 & 132 & 17 & 121 & 10 \\
Kuopio & 27.55 & 62.7333 & 190 & 129 & 84 & 194 & 15 \\
Lecce & 18.1 & 40.333 & 30 & 132 & 16 & 66 & 0 \\
Leipzig & 12.433 & 51.35 & 90 & 132 & 62 & 284 & 62 \\
Maisach & 11.258 & 48.209 & 516 & 132 & 5 & 15 & 4 \\
Melpitz & 12.93 & 51.53 & 84 & 23 & 6 & 18 & 4 \\
Naples & 14.183 & 40.838 & 118 & 33 & 8 & 32 & 5 \\
Potenza & 15.72 & 40.6 & 720 & 132 & 137 & 702 & 153 \\
Thessaloniki & 22.95 & 40.63 & 50 & 132 & 70 & 202 & 111 \\
Warsaw & 20.98 & 52.21 & 112 & 11 & 37 & 232 & 29 \\
\hline Total & & & & $\mathbf{1 8 4 5}$ & $\mathbf{1 1 2 9}$ & 4957 & $\mathbf{8 0 8}$ \\
\hline
\end{tabular}

\subsection{Neural Network Aerosol Typing Algorithm Based on Lidar Data: NATALI Software}

The aerosol typing of lidar data from the EARLINET database was done using the custom-made software NATALI (see Supplementary Materials). This classification algorithm has already been tested on synthetic and measurement data, and the entire processes of building up and software quality assurance are fully described in Nicolae D. et al. [20].

The NATALI software uses as input parameters the EARLINET database: the backscatter coefficient profiles at 1064, 532, and $355 \mathrm{~nm}$; the extinction coefficient profiles at 532 and $355 \mathrm{~nm}$; and optionally the linear particle depolarization profile at $532 \mathrm{~nm}$. Depending on the available input parameters and their quality, the typing can be done at three levels: (1) high-resolution typing when depolarization is available (14 aerosol types (pure, mixtures of two, and mixtures of three pure aerosol types) can be identified); (2) low-resolution typing when depolarization is available (six predominant aerosol types ( $70 \%$ pure aerosols with traces from other types) can be identified) (used especially when the uncertainty of the input data is high); and (3) low-resolution typing when depolarization is not available (5 predominant aerosol types can be identified). In this article, the typing was performed using option 3 (low-resolution typing when depolarization is not available) because the calibrated depolarization profiles were included only recently in the EARLINET observations and therefore were not available for most of the years analyzed in this article. Dust, Smoke, Continental, Continental Polluted, and Marine/Cloud were the aerosol types retrieved using the low-resolution typing part of the NATALI software. Their principal characteristics and sources are in the table below (Table 2), and they have been described in Nicolae D. et al. [20]. Marine aerosols and aerosol layers corrupted by clouds cannot be separated by the algorithm when using the low-resolution typing level due to their similar optical properties at the lidar wavelengths.

Table 2. Conventional names of the aerosol types [20].

\begin{tabular}{ccc}
\hline Aerosol Type & Source & Particle Characteristics \\
\hline Continental & Land surfaces & Medium size, medium spherical, medium absorbing \\
Dust & Desert surfaces & Large, nonspherical, medium absorbing \\
Continental polluted & Industrial sites & Small, spherical, highly absorbing \\
Marine & Sea surface & Large, aspherical, nonabsorbing \\
Smoke & Vegetation fires & Small, spherical, highly absorbing \\
\hline
\end{tabular}


NATALI software detects the layer boundaries with the gradient method [35] using the 1064-nm backscatter coefficient profile. For each layer, the aerosol mean intensive optical parameters are calculated using the three backscatter coefficients and the two extinction coefficients, as follows:

$$
\begin{gathered}
\mathrm{AE}_{\lambda_{1} / \lambda_{2}}=-\frac{\ln \alpha_{\lambda_{1}} / \alpha_{\lambda_{2}}}{\ln \lambda_{1} / \lambda_{2}}, \\
\mathrm{CI}_{\lambda_{1} / \lambda_{2}}=-\frac{\ln \beta_{\lambda_{1} / \beta_{\lambda_{2}}}}{\ln \lambda_{1} / \lambda_{2}}, \\
\mathrm{LR}_{\lambda_{1}}=\frac{\alpha_{\lambda_{1}}}{\beta_{\lambda_{1}}}, \\
\mathrm{CR}_{\lambda_{1} / \lambda_{2}}=\frac{\beta_{\lambda_{1}}}{\beta_{\lambda_{2}}}
\end{gathered}
$$

where $\alpha$ represents the extinction coefficient, $\beta$ the backscatter coefficient, and $\lambda$ the wavelength.

The entire set of parameters (i.e., AEs, color ratios (CRs), color indexes (CIs), and LRs and PDRs when available) was used as input for several ANNs upon which the typing process was based. The ANNs were built on a synthetic database constructed from a customized aerosol model able to reproduce the necessary observed aerosol properties in a statistically relevant number. At least 3500 samples of each aerosol type were used as input to the ANNs for supervised learning. A cascade of three ANNs with different architectures was established to perform the classification on each typing level in order to maximize the performance of the typing process. The predominant aerosol type was selected using a voting procedure applied to the responses of the three ANNs based on the ANN output confidence level and stability of answers. The NATALI software performance in retrieving the aerosol type is highly dependent on the physical content of the optical inputs and their uncertainty and availability, and the predominant aerosol types that are recognized in more than $70 \%$ of the cases with intensive optical parameters have uncertainties lower than 50\% [20].

\subsection{Clusterization Based on Typical Atmospheric Circulation}

To analyze the air masses carrying different aerosol types from various sources over Europe between 2008 and 2018, the GrossWetterTypes threshold-based catalogue with 18 circulation types (GWT18) was used [36]. The GWT classification catalogue was developed within COST 733 Action (the European Cooperation in Science and Technology) [37,38], and it organizes the maps into types according to varying degrees of zonality, meridionality, and vorticity determined as spatial correlation coefficients between daily sea level pressure fields and prototypical flow patterns [36].

The methodology proposed in COST 733 to identify circulation types was based on sea level pressure. In this article, instead of sea level pressure, a 850-hPa geopotential height was used, because this level is representative of the local circulation within the planetary boundary layer (PBL) and for long-range transport within the free troposphere. The geopotential height dataset was extracted from ECMWF ERA Interim Reanalysis (European Centre for Medium-Range Weather Forecasts) [39] at a $0.25^{\circ} \times 0.25^{\circ}$ horizontal resolution.

The analysis was performed in two steps. First, the circulation type around each station was assessed, and then the stations were grouped based on their common circulation features (Table 3). Around each cluster, an extended domain was defined (Figure 1). Second, the circulation types according to the GWT18 catalogue (not shown) were assessed for each cluster. The GWT18 catalogue discerned the dominant circulation over an area into cyclonic and anticyclonic types in eight cardinal and intercardinal directions (N, S, E, W, NE, SE, SW, NW) and discerned two undefined cyclonic and anticyclonic circulations. 
Table 3. The clusters of European Aerosol Research Lidar Network (EARLINET) and Aerosol Robotic Network (AERONET) stations and their spatial extent.

\begin{tabular}{ccc}
\hline Cluster & Spatial Extent (lon/lat) & Stations \\
\hline Central & $0^{\circ}-20^{\circ} \mathrm{E} / 40^{\circ}-60^{\circ} \mathrm{N}$ & Hohenspeissenberg, Leipzig, Maisach, and Melpitz \\
Southeast & $15^{\circ}-35^{\circ} \mathrm{E} / 30^{\circ}-50^{\circ} \mathrm{N}$ & Athens, Bucharest, and Thessaloniki \\
Mediterranean & $5^{\circ}-25^{\circ} \mathrm{E} / 30^{\circ}-50^{\circ} \mathrm{N}$ & Ispra, Lecce, Naples, and Potenza \\
Southwest & $15^{\circ} \mathrm{W}-10^{\circ} \mathrm{E} / 30^{\circ}-50^{\circ} \mathrm{N}$ & Barcelona, Evora, and Granada \\
Northwest & $10^{\circ} \mathrm{W}-10^{\circ} \mathrm{E} / 45^{\circ}-65^{\circ} \mathrm{N}$ & Cabaw \\
Northeast & $15^{\circ}-35^{\circ} \mathrm{E} / 45^{\circ}-65^{\circ} \mathrm{N}$ & Kuopio and Warsaw \\
\hline
\end{tabular}

\section{Results}

\subsection{Optical Characteristics of Aerosols over Europe}

Mean values of the aerosols' optical parameters for Europe are presented in Table 4 . These were obtained from EARLINET observations between 2008 and 2018. In total, 4957 layers were analyzed, and for each layer, the optical parameters (i.e., backscatter coefficients at 1064, 532, and 355 nm, extinction coefficients at 532 and $355 \mathrm{~nm}$ ) were used to calculate the intensive optical parameters (Equations (1)-(3)). Table 4 shows the mean values obtained for all layers passing the QA criteria (808 layers) and their associated standard deviations. Based on the inversely proportional relationship between Angstrom exponents and the particle radius (e.g., References [40,41]), the results indicate that the typical aerosol particles observed during the study period over Europe were medium-sized absorbing particles with low spectral dependence (i.e., relatively similar values for the parameters in Table 4 [42]).

Table 4. Mean values of the intensive optical parameters over Europe between 2008 and 2018 as retrieved from EARLINET lidar measurements (808 layers that passed the QA criteria).

\begin{tabular}{cc}
\hline Parameter & Mean Value and Standard Deviation \\
\hline Angstrom exponent $(355 / 532 \mathrm{~nm})$ & $1.18 \pm 0.14$ \\
Color index $(355 / 532 \mathrm{~nm})$ & $1.31 \pm 0.13$ \\
Color index $(532 / 1064 \mathrm{~nm})$ & $0.93 \pm 0.08$ \\
Lidar ratio $(355 \mathrm{~nm})$ & $62 \pm 3 \mathrm{sr}$ \\
Lidar ratio $(532 \mathrm{~nm})$ & $67 \pm 4 \mathrm{sr}$ \\
\hline
\end{tabular}

Differences between the optical properties of aerosols in different regions of Europe were analyzed. Figure 2 shows the mean aerosol intensive optical parameters for each geographical cluster, calculated from EARLINET lidar measurements and AERONET data. Although collocated, the two measurement techniques did not sample the same atmosphere because the Raman lidars are usually operated during nighttime, while the photometers are usually operated during daytime. This may introduce systematic biases when comparisons are conducted directly. In addition, lidar does not detect low-level aerosols in the first part of the planetary boundary layer (approximatively 200 up to $800 \mathrm{~m}$ ) due to its technological limitations (the overlap issue [5]). This may also introduce biases as long as the locally produced aerosols are generally confined in the PBL and the lidar cannot measure their specific characteristics. 

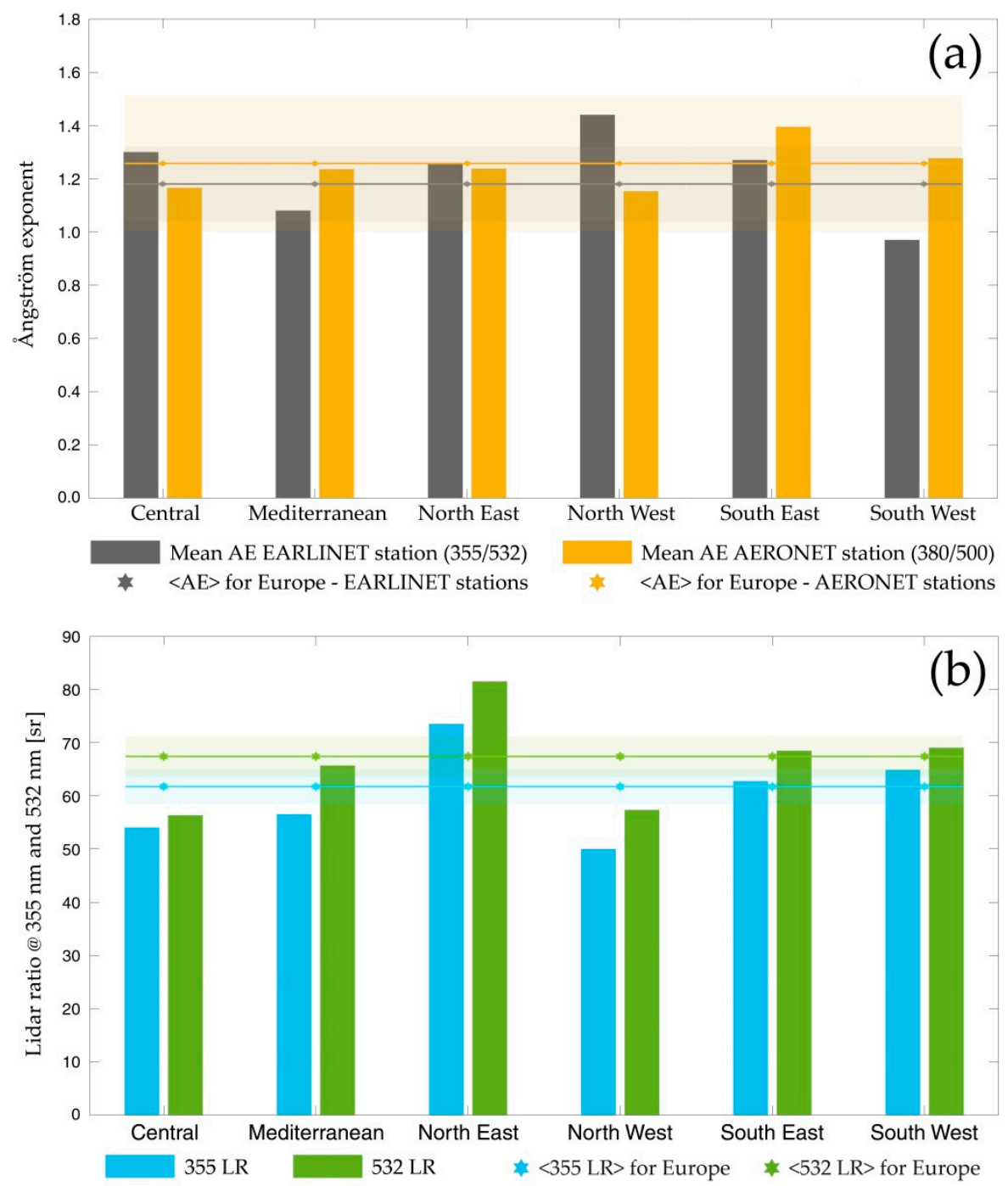

Figure 2. Optical properties of aerosols as retrieved from EARLINET lidar measurements and AERONET photometer measurements between 2008 and 2018: (a) mean values of Angstrom exponents from lidar (355/532 nm, dark gray bar) and from photometers (380/500 nm, orange bar) for each cluster; (b) mean values of lidar ratios from lidar at $355 \mathrm{~nm}$ (blue bar) and $532 \mathrm{~nm}$ (green bar) for each cluster. The mean European values (dark gray and orange lines for the Angstrom exponents and blue and green lines for the lidar ratios) and the standard deviations (shaded) are indicated.

The lowest mean values for the Angstrom exponent (i.e., 0.97) were observed over the Iberian Peninsula (Southwest cluster) and were associated with Dust and Marine particles (Figure 2a). The highest mean values for the lidar ratio at $532 \mathrm{~nm}$ (i.e., $82 \mathrm{sr}$ ) were recorded over Northeastern Europe and were associated with Smoke (Figure 2b).

Figure 3 shows the aerosol optical properties (i.e., AODs at $500 \mathrm{~nm}$ and Angstrom exponents at 380/500 nm) for each geographical cluster and season, calculated from AERONET photometer measurements. In total, 1845 monthly averaged values of AODs and AEs were used. 

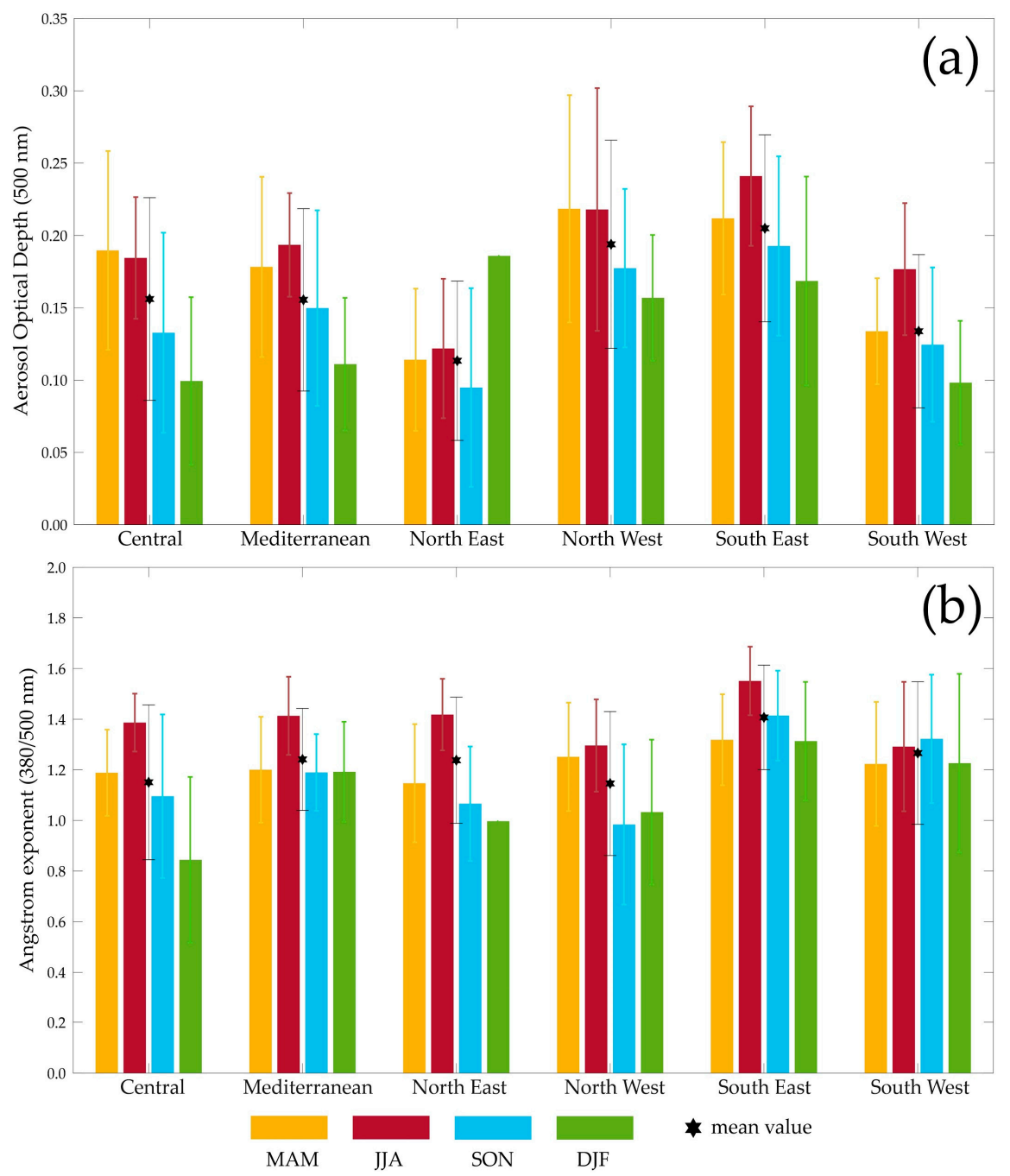

Figure 3. Optical properties of aerosols as retrieved from AERONET photometer measurements between 2008 and 2018: (a) aerosol optical depths (AODs) (500 nm) and (b) Angstrom exponents (AEs) $(380 / 500 \mathrm{~nm})$. The mean values and the standard deviations for the AODs and AEs for each cluster are indicated by a black marker and whiskers.

High AOD values (i.e., 0.3) were observed during summer over the Southeast (Figure 3a). The Northeast cluster was characterized by low AOD values for all seasons (with the exception of winter), which can be explained by cleaner air conditions compared to the other clusters (e.g., Reference [43]). The highest values for AE were observed during summer (i.e., months JJA (June, July, August)) and varied from 1.29 for the Southwest and Northwest clusters to 1.55 for the Southeast cluster. These high values can be explained by the presence of small particles (e.g., smoke) transported in the troposphere (Figure $3 b$ ). The smallest values for AE were recorded during winter (i.e., months DJF (December, January, February)) for all clusters, with the exception of the Northwest cluster, where the smallest AE values were recorded during autumn (i.e., months SON (September, October, November)) (Figure 3b) (e.g., Reference [13]).

\subsection{Aerosol Types over Europe}

The distribution of aerosol types in Europe shows that Smoke (37\%) and Continental (25\%) aerosol types were identified by NATALI software as the predominant aerosol types in Europe, followed by the Continental Polluted type (17\%) and Marine/Cloud (10\%). Dust $(10 \%)$ is generally transported from the Sahara, but there is also a contribution from soil dust. Approximately $1 \%$ of the analyzed 
cases were not recognized by NATALI. Differences between aerosol types in different regions of Europe are shown in Figure 4.

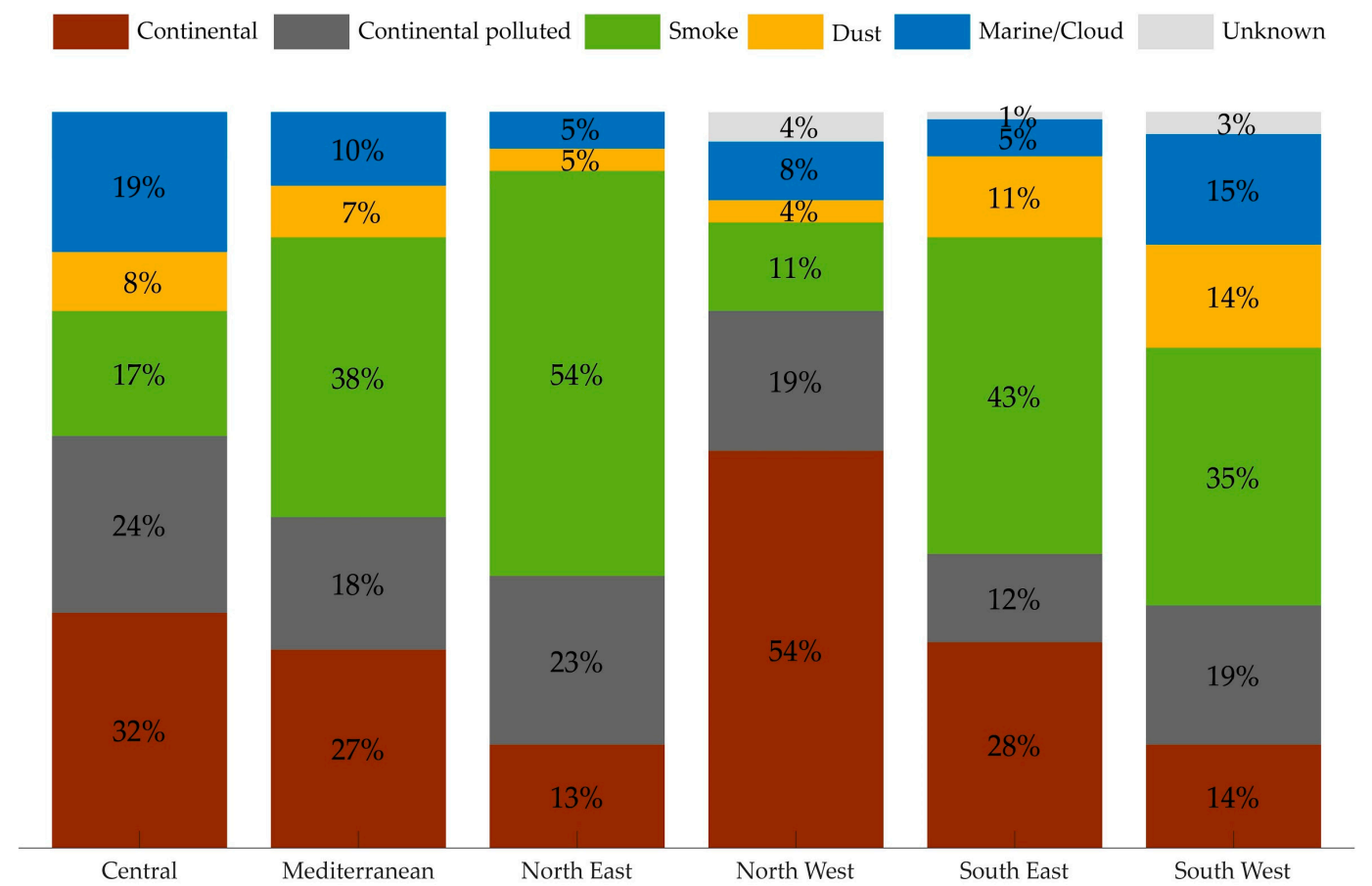

Figure 4. Prevalence of aerosol types retrieved with the Neural network Aerosol Typing Algorithm based on LIdar data (NATALI) code from EARLINET lidar measurements between 2008 and 2018.

The dominant aerosol type was Continental for the Northwest (54\%) and Central (32\%) clusters. The Marine/Cloud type was more frequently identified over Central Europe (19\%) and the Southwest $(15 \%)$, but this type was also present in the Mediterranean (10\%) cluster. The high percentage obtained for Central Europe was very likely due to incomplete cloud screening, taking into account the drawback of the algorithm in the low-resolution typing level in separating the marine and cloud corrupted layers.

Over the Northeast (54\%), Southeast (43\%), and Mediterranean (38\%), Smoke was the dominant aerosol type. This was most likely due to the forest fires that occur frequently over the Ukraine, the Russian Federation, Greece, and Turkey [44,45]. Smoke from Africa is also transported over the Iberian Peninsula and into the Mediterranean region [46].

In order to explain the aerosol types retrieved with NATALI code, for each domain, the GWT18 circulation types corresponding to the date of EARLINET measurements were analyzed (Figure 5). For the Central cluster, the dominant circulation type was western $(34.9 \%)$, which enabled humid air mass advections from the Atlantic Ocean toward the Central domain, while the Southwestern circulation type (17.9\%) enabled the transport of dry and hot air masses from North Africa. The western circulation explained the Marine/Cloud type and also part of the Smoke aerosols of North American origin [47]. The southwestern circulations enabled the Dust particle advection and also Smoke aerosols from Iberian Peninsula summer fires. The percentage of undefined anticyclonic circulation types $(12.3 \%)$ was also remarkable, which is the signature of local circulation and could explain the high percentage of Continental and Continental Polluted aerosol types, as it is known that Central and Eastern Europe are powerful industrial areas known as "the black triangle" [48].

The northern, northwestern, and western anticyclonic circulation types over the Mediterranean cluster were quasi-equally represented (approx. 15\% each), while northeastern circulations were $10.7 \%$ and southwestern circulations were $7.3 \%$. The northern and northeastern circulation types were responsible for Continental and Continental Polluted aerosols, since the air masses cross "the black triangle". Western and northwestern circulations were responsible for long-range transport of 
Smoke particles [49-51]. Southwestern circulations were mainly responsible for Dust particles and for Marine/Cloud aerosols.

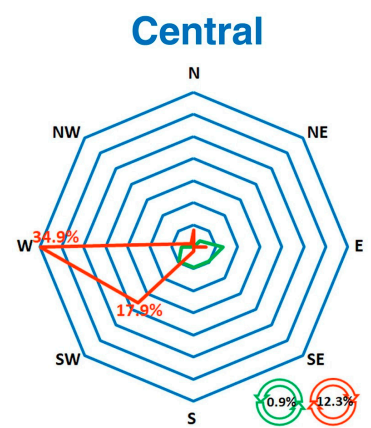

North West

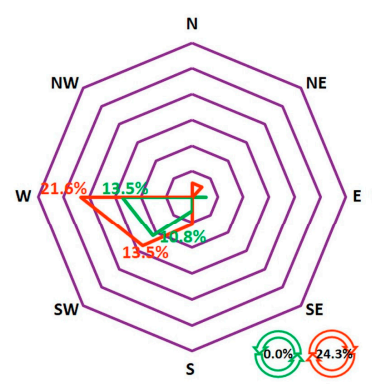

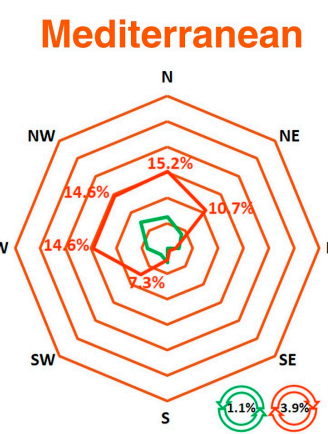

South East

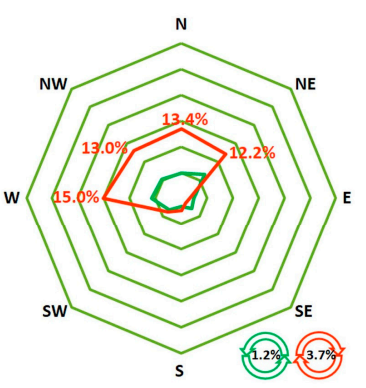

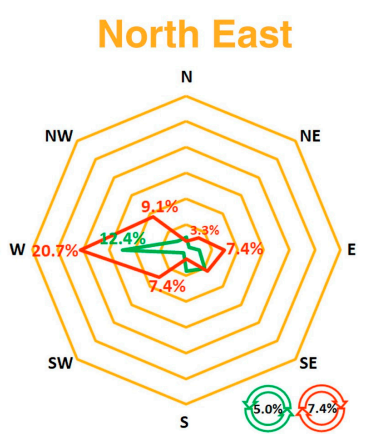

South West

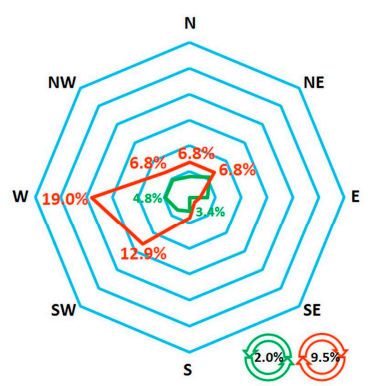

Figure 5. Circulation types based on the GWT18 circulation type catalogue corresponding to the clusters described in Figure 1 (color-coded accordingly with the colors for each cluster). Only data corresponding with the time of EARLINET lidar measurements were used. For each cluster, the wind direction is shown for cyclonic (red line) and anticyclonic (green line) circulations. The percentage shown for each cluster represents the total number of observations of the dominant wind direction. For each cluster, the percentage of undefined cyclonic (green circle) and anticyclonic (red circle) circulation is shown.

The dominant circulation type over the Northeastern cluster was western anticyclonic (20.7\%) and cyclonic (12.4\%), which explains the presence of Continental and Continental Polluted aerosols but also enabled the long-range transport of Smoke particles from North America $[52,53]$ and from local fires [54]. Smoke aerosols from the Ukraine and the Russian Federation were also enabled by eastern $(7.4 \%)$ and northeastern circulations (3.3\%). The northwestern circulation type $(9.1 \%)$ enabled the advection of Marine aerosols from the Baltic Sea, while southwestern circulation (7.4\%) allowed the dry air masses to advect Dust particles from North Africa and Smoke particles from western Balkan fire events.

The highest percentage of circulation types over the Northwestern cluster was anticyclonic undefined (24.3\%), which explains the highest percentage of Continental and Continental Polluted particles due to subsidence. The western circulation, both anticyclonic $(21.6 \%)$ and cyclonic $(13.5 \%)$, explained the trans-Atlantic transport of Smoke particles [55-57] and marine aerosols. The southwestern anticyclonic circulation (13.5\%) was linked with Dust events [58] and Iberian fire events [59], while the cyclonic circulation (10.8\%) explained the presence of Marine/Clouds.

The Southeastern cluster was characterized by western (15\%), northern $(13.4 \%)$, northwestern $(13.0 \%)$, and northeastern (12.2\%) anticyclonic circulation types. These circulation types were linked with Continental and Continental Polluted (western and northwestern circulations) and Smoke aerosols (northern and northeastern circulations). Southwestern circulations were mostly linked with Dust events, while southern, southeastern, and eastern circulation types were associated with Marine/Clouds.

Western (19.0\% anticyclonic, 4.8\% cyclonic) and southwestern (12.9\% anticyclonic, $3.4 \%$ cyclonic) circulation types characterized the Southwestern cluster, explaining the presence of Dust particles [60] 
and Marine/Clouds. In addition, northwestern and northern and eastern circulations allowed the humid air masses to transport Marine/Clouds from the Atlantic and the Mediterranean Sea toward the Iberian Peninsula. The northeastern (6.8\%) circulation type, together with the anticyclonic undefined $(9.5 \%)$ circulations, explained the presence of Continental and Continental Polluted aerosols either from France or that were locally generated. Due to prolonged droughts and high temperatures during the warm seasons, numerous fire events were reported in Portugal and Spain (http://effis.jrc.ec.europa.eu/reports-and-publications/annual-fire-reports/ and Reference [59]).

Seasonal variation of aerosols over Europe is shown in Figure 6a. In this plot, the results are presented as percentages of the total number of aerosol layers observed during a certain season and between 2008 and 2018 to put into evidence the frequency of occurrence of different aerosol types. However, the number of layers varied with the season because of weather conditions, which made the sampling over the seasons inhomogeneous: a clear sky in summer (399 layers) and the presence of low clouds or precipitation in spring (203 layers), winter (72 layers), and autumn (134 layers). In addition, it should be noted that NATALI is not able to distinguish between Marine aerosols and aerosol layers corrupted by clouds. Cloud particles are large and low absorbing and are therefore very similar to Marine aerosols [20]. As such, lidar observations that are not completely cloud-free may result in a false classification as Marine. This is particularly true for the winter season, when the atmosphere is generally cloudy and lidar measurements are performed between broken clouds.

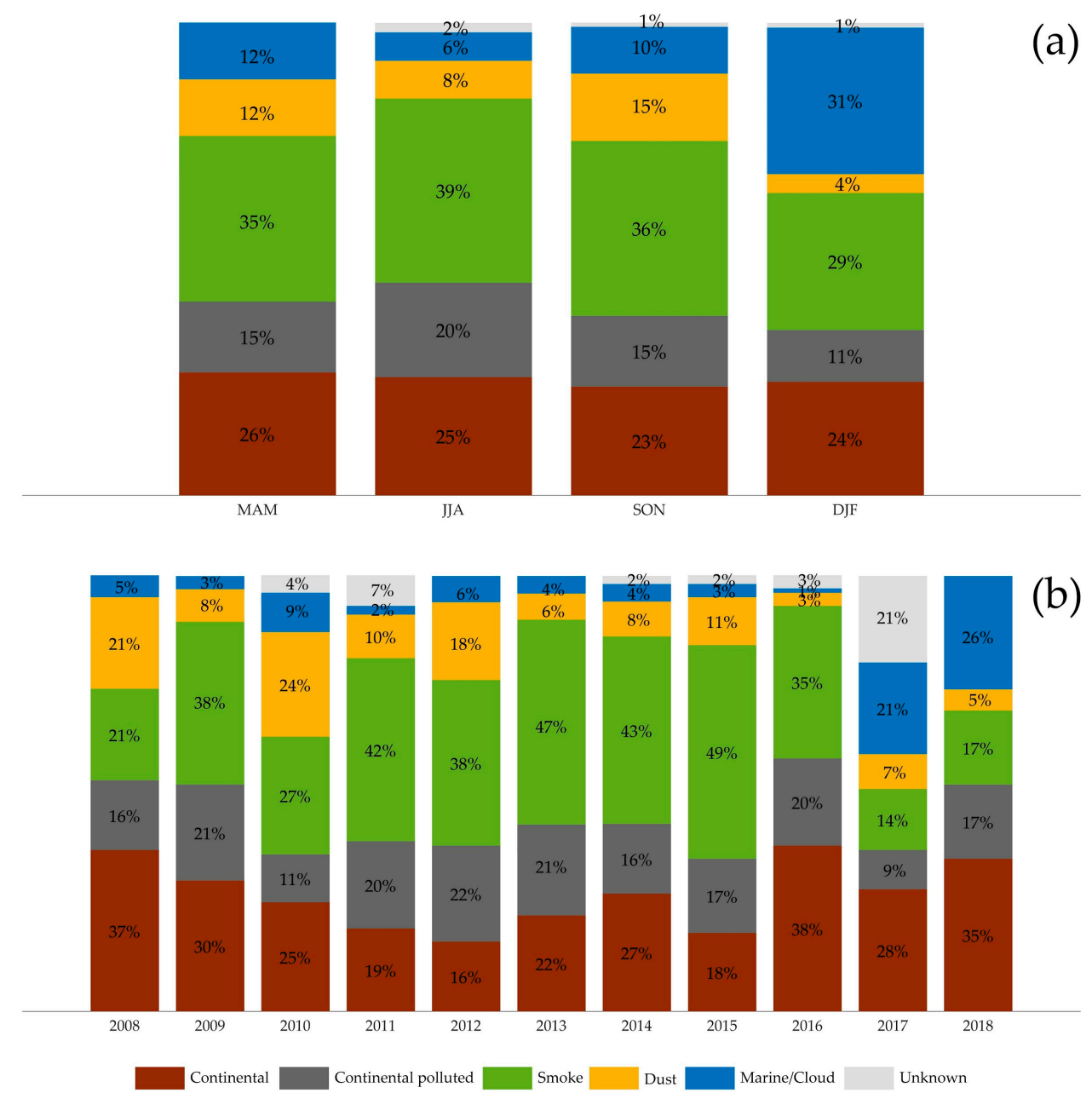

Figure 6. Time distribution of the prevalence of aerosol types retrieved with the NATALI code from EARLINET lidar measurements between 2008 and 2018: (a) seasonal distribution, (b) annual variations. 
Except for winter (fewer data and potentially corrupted by clouds), the seasonal variability was insignificant at a continental scale: small increases in the percentage of Smoke during spring and small increases in Dust during autumn (out of the total number of layers measured in each season) (Figure 6a). The variation of aerosol types over Europe showed that the proportions of aerosol types varied each year, being influenced by long-range transport from other continents and by the meteorological situation.

Figure $6 \mathrm{~b}$ shows that there was significant production and transport of biomass burning aerosols between 2011 and 2015 [4,47,61], while Dust transport increased in 2008, 2010, and 2012 [5,61]. The Dust category included, besides mineral dust, also volcanic dust due to the similar intensive optical parameters, which explains the increase in the percentage of Dust in 2010, when volcanic ash from the Eyjafjallajokull volcano was injected in the troposphere and transported over Europe [62]. In recent years (i.e., 2017-2018), more Marine/Clouds were identified by the NATALI algorithm. These data were not finalized in the EARLINET database, i.e., not all quality assurance procedures applied, and therefore biases due to an incomplete cloud screening may apply.

The years with a high percentage of Smoke in Figure $6 \mathrm{~b}$ generally corresponded with the years with high temperatures and prolonged droughts, which were the key drivers of warm season fires across the European region [63]. Since the beginning of the 21st century, Europe has experienced a series of extreme hot and dry summers [64] covering different parts of the continent. The years of $2014(43 \%)$ and $2015(49 \%)$ were among the top 10 European record-breaking heatwave events since $1950[65,66]$. Heat waves episodes were recorded almost every summer in different European regions. According to the Joint Research Centre's annual reports on "Forest Fires in Europe, the Middle East, and North Africa" (http://effis.jrc.ec.europa.eu/reports-and-publications/annual-fire-reports/), the most affected European area was the Mediterranean region (Portugal, Spain, France, Italy, and Greece). The highest peaks of fire activities for this region were registered during the entire analyzed period excepting 2010 and 2014. In addition, fire events were recorded in western, central, and northern Europe during 2011 and 2013-2018. Smoke particles of North American forest fire origin were reported over the Mediterranean Basin in 2013 [49,50] and 2014 [51], over western Europe in 2017 [56], over northern Europe in 2016 [55], and over central Europe in 2013 [47,52] and 2015 [53].

The annual variability of the optical properties of aerosols over Europe is presented in Figure 7, as obtained from AERONET measurements. The European mean values are highlighted in the time evolution of the AOD and AE for all clusters (including the standard deviations as shaded areas) using linear and fourth-grade polynomial fits, respectively (black lines). The decreasing trend of the AOD is clearly visible in these results, and the linear fit of the European mean values had a correlation coefficient of 0.62. The AOD trend pointed to an overall decrease in the aerosol concentration in Europe, probably due to the implementation of environmental policies [67-69]. However, large values of AODs were measured in the Southeast in 2008 and 2011 [3], as well as in the Northwest in 2015 [70]. In these regions, the AOD was always above the European mean, pointing to higher concentrations of aerosols but of different types. In the Southeast, the high AODs were associated with persistent Smoke transport in the troposphere from the east and south, while in the Northwest, the high AODs were more related to the transport of Continental Polluted aerosol from Central Europe on top of locally produced particles. The Northeast and Southwest were constantly the "cleanest" regions in Europe, i.e., having the smallest AOD values recorded by AERONET. 

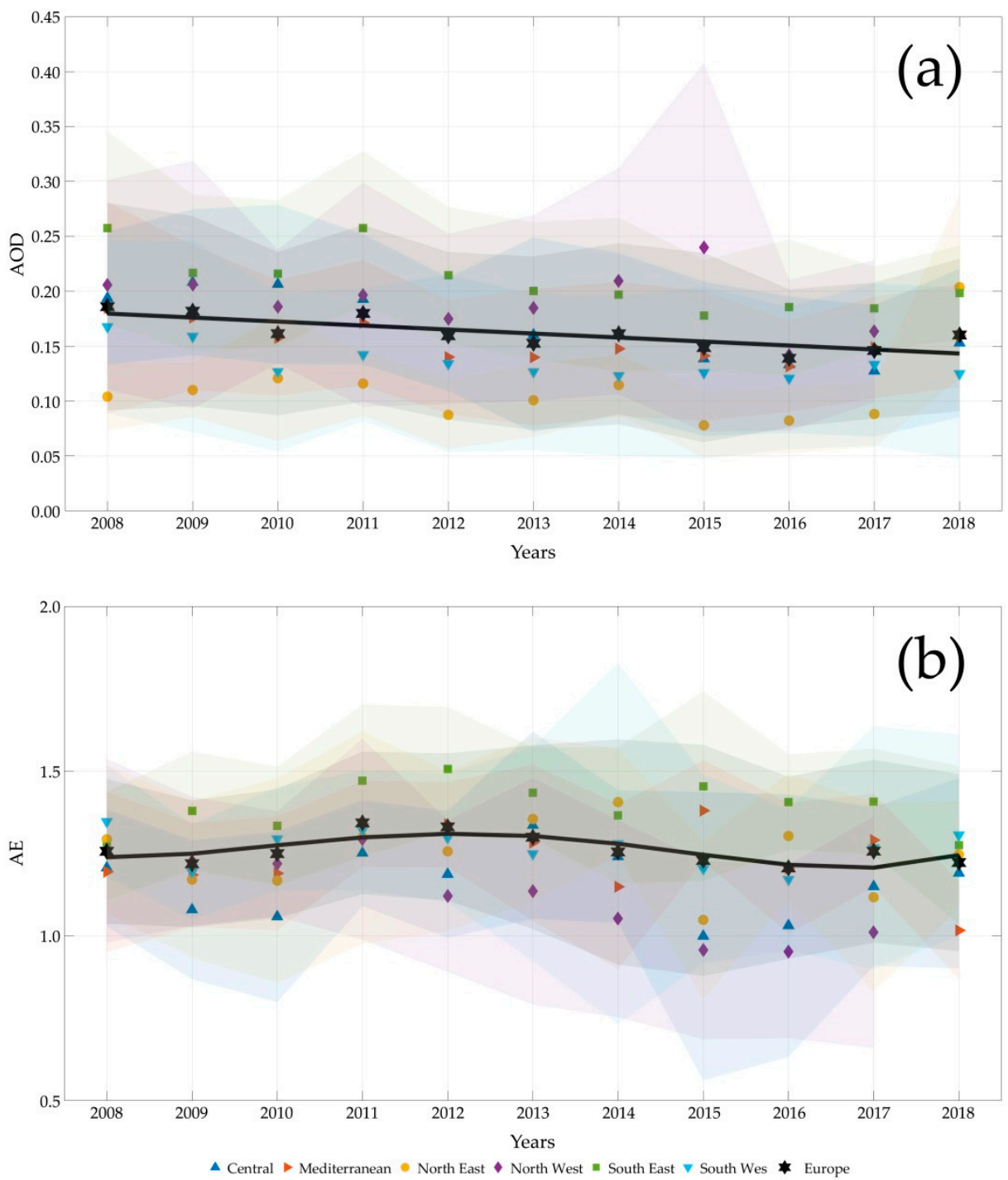

Figure 7. Changes in the aerosol optical properties over Europe between 2008 and 2018 as measured by AERONET photometers: (a) time evolution of the aerosol optical depths $(500 \mathrm{~nm})$; (b) time evolution of the Angstrom exponents (380/500 nm). Black lines represent the linear and fourth-grade polynomial fit of the European mean values, and the shaded areas represent the standard deviations.

Aerosol AEs varied over Europe with values greater than 1.2 between 2011 and 2014 and values lower than 1.2 for the rest of the study period. The high values of AEs were associated with an increased proportion of Smoke over Europe (Figure 7b). The largest value for the AEs (i.e., 1.5) was recorded for the Southeast cluster in 2012, very likely associated with the transport of biomass burning aerosols over Bucharest and Athens. An interesting feature is the change in the AE in the Northwest region, from values around the European mean between 2008 and 2011 to very low values starting in 2012. The Southeast and Mediterranean regions seemed to have the same phase of oscillations for the AE, opposite to Central Europe. The years 2012 and 2015 were characterized by high AEs (small particles) in the southeast and Mediterranean clusters, but low AEs (larger particles) in central Europe. On the contrary, in 2013, the AE decreased in the Southeast and Mediterranean regions and increased in Central Europe.

In general, the differences between regions in terms of $\mathrm{AE}$ values (and therefore the size of the particles) increased with time. The values of the Angstrom exponent varied significantly from year to year, showing an important contribution from the long-range transported aerosols to the total aerosol load in the column. 


\section{Conclusions}

In this study, aerosols over Europe were characterized based on lidar and photometer observations collected between 2008 and 2018 by the EARLINET (European Aerosol Research Lidar Network) and AERONET (Aerosol Robotic Network). Seventeen observing stations distributed over six regions in Europe and operating both multiwavelength Raman lidars and automatic sun/sky photometers were selected.

In order to retrieve the aerosol type, NATALI (Neural Network Aerosol Typing Algorithm Based on Lidar Data) software was used. NATALI identifies the aerosol layer boundaries with the gradient method applied on the backscatter coefficient at $1064 \mathrm{~nm}$, calculates the mean layer aerosol intensive optical parameters, and runs a combination of artificial neural networks to identify the most probable aerosol type that fits the optical data.

The analysis showed that the typical aerosol particle observed over Europe between 2008 and 2018 was of medium size, had medium absorbing particles, and had low spectral dependence. The aerosol properties had a large variability in time (from season to season and year to year) compared to the variability in space (from region to region) and were largely influenced by long-range transport from other continents and by large-scale circulation.

Smoke was more present in the East (55\% out of all layers observed in the North and $43 \%$ in the South) but could also be found in the Mediterranean region (38\%) and over the Iberian Peninsula (35\%) due to frequent transport from Africa. Central and Northwestern Europe were generally dominated by the Continental aerosols ( $32 \%$ and $54 \%$, respectively). Dust (locally produced soil dust and long-range transported desert dust) was measured all over Europe, as already highlighted by several papers, but mostly in autumn (15\%) and spring $(12 \%)$, when it is lifted by the turbulent air masses above the PBL. Continental Polluted aerosols represented a high proportion (17\%) of all aerosol types in Europe, although the decreasing AOD may have been partially related to the implementation of European environmental regulations.

Years with high temperatures in Europe (2011-2015) were highlighted also by an increase in the Angstrom exponent measured by AERONET $(>1.3)$ as well as by an increase in the proportion of Smoke particles derived by NATALI from EARLINET observations (more than $35 \%$ out of the total number of aerosol layers).

Based on the decadal variation of the Angstrom exponents, these "hot and smoky" years (2011-2015) seemed to be balanced by "dusty" years (2008-2010) and "wet" years (2017-2018); however, they were not equal in all parts of Europe. The high variability from year to year showed that aerosol transport in the troposphere became more and more important in the overall balance of the columnar aerosol load and that regional characteristics were no longer linked to close-by aerosol sources but to dominant circulations bringing dust and biomass burning aerosols from other continents.

Supplementary Materials: The NATALI (Neural Network Aerosol Typing Algorithm Based on Lidar Data) software is available with a user guide from http://natali.inoe.ro/resources.html/software.

Author Contributions: Conceptualization, D.N.; methodology, S.A., D.E., and J.V.; software, V.N. and T.S.; formal analysis, C.T. and A.D.; investigation, S.A. and B.A.; writing-original draft preparation, B.A. and V.N; writing-all authors; writing-review and editing, B.A and J.V.; visualization, D.E. and V.-E.T.; supervision, D.N. and S.S.

Funding: This research was funded by the Ministry of Research and Innovation through Program I-Development of the national research development system, Subprogram 1.2-Institutional Performance-Projects of Excellence Financing in RDI, Contract No.19PFE/17.10.2018, by the Romanian National Core Program Contract No.18N/2019; by the RDI Program for Space Technology and Advanced Research contract 183/2017; and by the European Regional Development Fund through the Competitiveness Operational Programme 2014-2020, POC-A.1-A.1.1.1-F-2015, project Research Centre for environment and Earth Observation CEO-Terra, SMIS code 108109, contract No. 152/2016. Camelia Talianu was supported by the Austrian Science Fund (FWF), Project M 2031, Meitner-Programm.

Acknowledgments: The authors acknowledge EARLINET for providing aerosol lidar profiles available from the EARLINET webpage. We would like to acknowledge the AERONET team for calibrating and processing the data and to thank the principal investigators and their staff for maintaining the 17 sites identified in Section 2.1.

Conflicts of Interest: The authors declare no conflict of interest. 


\section{References}

1. Wang, H.; Xie, X.; Liu, X. On the Robustness of the Weakening Effect of Anthropogenic Aerosols on the East Asian Summer Monsoon with Multimodel Results. Adv. Meteorol. 2015, 2015, 397395. [CrossRef]

2. Farahat, A. Comparative analysis of MODIS, MISR, and AERONET climatology over the Middle East and North Africa. Ann. Geophys. 2019, 37, 49-64. [CrossRef]

3. Siomos, N.; Balis, D.S.; Voudouri, K.A.; Giannakaki, E.; Filioglou, M.; Amiridis, V.; Papayannis, A.; Fragkos, K. Are EARLINET and AERONET climatologies consistent? The case of Thessaloniki, Greece. Atmos. Chem. Phys. 2018, 18, 11885-11903. [CrossRef]

4. Georgoulias, A.K.; Alexandri, G.; Kourtidis, K.A.; Lelieveld, J.; Zanis, P.; Pöschl, U.; Levy, R.; Amiridis, V.; Marinou, E.; Tsikerdekis, A. Spatiotemporal variability and contribution of different aerosol types to the aerosol optical depth over the Eastern Mediterranean. Atmos. Chem. Phys. 2016, 16, 13853-13884. [CrossRef] [PubMed]

5. Wandinger, U.; Freudenthaler, V.; Baars, H.; Amodeo, A.; Engelmann, R.; Mattis, I.; Groß, S.; Pappalardo, G.; Giunta, A.; D'Amico, G.; et al. EARLINET instrument intercomparison campaigns: Overview on strategy and results. Atmos. Meas. Tech. 2016, 9, 1001-1023. [CrossRef]

6. Pappalardo, G.; Amodeo, A.; Apituley, A.; Comeron, A.; Freudenthaler, V.; Linné, H.; Ansmann, A.; Bösenberg, J.; D’Amico, G.; Mattis, I.; et al. EARLINET: Towards an advanced sustainable European aerosol lidar network. Atmos. Meas. Tech. 2014, 7, 2389-2409. [CrossRef]

7. Burton, S.P.; Ferrare, R.A.; Vaughan, M.A.; Omar, A.H.; Rogers, R.R.; Hostetler, C.A.; Hair, J.W. Aerosol classification from airborne HSRL and comparisons with the CALIPSO vertical feature mask. Atmos. Meas. Tech. 2013, 6, 1397-1412. [CrossRef]

8. Groß, S.; Esselborn, M.; Weinzierl, B.; Wirth, M.; Fix, A.; Petzold, A. Aerosol classification by airborne high spectral resolution lidar observations. Atmos. Chem. Phys. 2013, 13, 2487-2505. [CrossRef]

9. Papagiannopoulos, N.; Mona, L.; Amodeo, A.; D’Amico, G.; Gumà Claramunt, P.; Pappalardo, G.; Alados-Arboledas, L.; Guerrero-Rascado, J.L.; Amiridis, V.; Kokkalis, P.; et al. An automatic observation-based aerosol typing method for EARLINET. Atmos. Chem. Phys. 2018, 18, 15879-15901. [CrossRef]

10. Wandinger, U.; Baars, H.; Engelmann, R.; Hünerbein, A.; Horn, S.; Kanitz, T.; Donovan, D.; van Zadelhoff, G.-J.; Daou, D.; Fischer, J.; et al. HETEAC: The Aerosol Classification Model for EarthCARE. EPJ Web Conf. 2016, 119, 01004. [CrossRef]

11. Holben, B.N.; Eck, T.F.; Slutsker, I.; Tanre, D.; Buis, J.P.; Setzer, A.; Vermote, E.; Reagan, J.A.; Kaufman, Y.; Nakajima, T.; et al. AERONET_A federated instrument network and data archive for aerosol characterization. Remote Sens. Environ. 1998, 66,1-16. [CrossRef]

12. Giles, D.M.; Sinyuk, A.; Sorokin, M.G.; Schafer, J.S.; Smirnov, A.; Slutsker, I.; Eck, T.F.; Holben, B.N.; Lewis, J.R.; Campbell, J.R.; et al. Advancements in the Aerosol Robotic Network (AERONET) Version 3 database automated near-real-time quality control algorithm with improved cloud screening for Sun photometer aerosol optical depth (AOD) measurements. Atmos. Meas. Tech. 2019, 12, 169-209. [CrossRef]

13. Giles, D.M.; Holben, B.N.; Eck, T.F.; Sinyuk, A.; Smirnov, A.; Slutsker, I.; Dickerson, R.; Thompson, A.; Schafer, J. An analysis of AERONET aerosol absorption properties and classifications representative of aerosol source regions. J. Geophys. Res. Atmos. 2012. [CrossRef]

14. Shin, S.-K.; Tesche, M.; Noh, Y.; Müller, D. Aerosol-type classification based on AERONET version 3 inversion products. Atmos. Meas. Tech. Discuss. 2019, 12, 3789-3803. [CrossRef]

15. Tan, F.; Lim, H.S.; Abdullah, K.; Yoon, T.L.; Holben, B. AERONET data-based determination of aerosol types. Atmos. Pollut. Res. 2015, 6, 682-695. [CrossRef]

16. Russell, P.B.; Bergstrom, R.W.; Shinozuka, Y.; Clarke, A.D.; DeCarlo, P.F.; Jimenez, J.L.; Livingston, J.M.; Redemann, J.; Dubovik, O.; Strawa, A. Absorption Angstrom Exponent in AERONET and related data as an indicator of aerosol composition. Atmos. Chem. Phys. 2010, 10, 1155-1169. [CrossRef]

17. Eck, T.F.; Holben, B.N.; Reid, J.S.; Sinyuk, A.; Hyer, E.J.; O’Neill, N.T.; Shaw, G.E.; Vande Castle, J.R.; Chapin, F.S.; Dubovik, O.; et al. Optical properties of boreal region biomass burning aerosols in central Alaska and seasonal variation of aerosol optical depth at an Arctic coastal site. J. Geophys. Res. 2009, 114, D11201. [CrossRef] 
18. Nemuc, A.; Vasilescu, J.; Talianu, C.; Belegante, L.; Nicolae, D. Assessment of aerosol's mass concentrations from measured linear particle depolarization ratio (vertically resolved) and simulations. Atmos. Meas. Tech. 2013, 6, 3243-3255. [CrossRef]

19. Groß, S.; Freudenthaler, V.; Wirth, M.; Weinzierl, B. Towards an aerosol classification scheme for future EarthCARE lidar observations and implications for research needs. Atmos. Sci. Lett. 2015, 16, 77-82. [CrossRef]

20. Nicolae, D.; Vasilescu, J.; Talianu, C.; Binietoglou, I.; Nicolae, V.; Andrei, S.; Antonescu, B. A neural network aerosol-typing algorithm based on lidar data. Atmos. Chem. Phys. 2018, 18, 14511-14537. [CrossRef]

21. Mamun, M.M.; Müller, D. Retrieval of Intensive Aerosol Microphysical Parameters from Multiwavelength Raman/HSRL Lidar: Feasibility Study with Artificial Neural Networks. Atmos. Meas. Tech. Discuss. 2016. [CrossRef]

22. Lanzaco, B.L.; Olcese, L.E.; Palancar, G.G.; Toselli, B.M. An Improved Aerosol Optical Depth Map Based on Machine-Learning and MODIS Data: Development and Application in South America. Aerosol. Air. Qual. Res. 2017, 17, 1623-1636. [CrossRef]

23. Gangwar, R.K.; Mathur, A.K.; Gohil, B.S.; Basu, S. Neural Network Based Retrieval of Atmospheric Temperature Profile Using AMSU-A Observations. Int. J. Atmos. Sci. 2014, 2014, 763060. [CrossRef]

24. EARLINET. EARLINET Data Portal. Available online: https://data.earlinet.org/earlinet/login.zul;jsessionid= AA323AC6D1261F5B01BF3203A131CA84 (accessed on 1 April 2019).

25. AERONET. Available online: https://aeronet.gsfc.nasa.gov/cgi-bin/draw_map_display_aod_v3 (accessed on 1 April 2019).

26. Ansmann, A.; Riebesell, M.; Wandinger, U.; Weitkamp, C.; Voss, E.; Lahmann, W.; Michaelis, W. Combined raman elastic-backscatter LIDAR for vertical profiling of moisture, aerosol extinction, backscatter, and LIDAR ratio. Appl. Phys. B 1992, 55, 18-28. [CrossRef]

27. Fernald, F.G. Analysis of atmospheric lidar observations: Some comments. Appl. Opt. 1984, 23, 652-653. [CrossRef] [PubMed]

28. Klett, J.D. Stable analytical inversion solution for processing lidar returns. Appl. Opt. 1981, 20, $211-220$. [CrossRef]

29. Freudenthaler, V. About the effects of polarising optics on lidar signals and the $\Delta 90$ calibration. Atmos. Meas. Tech. 2016, 9, 4181-4255. [CrossRef]

30. Belegante, L.; Bravo-Aranda, J.A.; Freudenthaler, V.; Nicolae, D.; Nemuc, A.; Ene, D.; Alados-Arboledas, L.; Amodeo, A.; Pappalardo, G.; D'Amico, G.; et al. Experimental techniques for the calibration of lidar depolarization channels in EARLINET. Atmos. Meas. Tech. 2018, 11, 1119-1141. [CrossRef]

31. D'Amico, G.; Amodeo, A.; Baars, H.; Binietoglou, I.; Freudenthaler, V.; Mattis, I.; Wandinger, U.; Pappalardo, G. EARLINET Single Calculus Chain-Overview on methodology and strategy. Atmos. Meas. Tech. 2015, 8, 4891-4916.

32. Dubovik, O.; King, M.D. A flexible inversion algorithm for retrieval of aerosol optical properties from Sun and sky radiance measurements. J. Geophys. Res. 2000, 105, 20673-20696. [CrossRef]

33. Dubovik, O.; Holben, B.N.; Eck, T.F.; Smirnov, A.; Kaufman, Y.J.; King, M.D.; Tanre, D.; Slutsker, I. Variability of absorption and optical properties of key aerosol types observed in worldwide locations. J. Atmos. Sci. 2002, 59, 590-608. [CrossRef]

34. Soni, K.; Singh, S.; Bano, T.; Tanwar, R.S.; Nath, S. Wavelength Dependence of the Aerosol Angstrom Exponent and Its Implications Over Delhi, India. Aerosol. Sci. Tech. 2011, 45, 1488-1498. [CrossRef]

35. Belegante, L.; Nicolae, D.; Nemuc, A.; Talianu, C.; Derognat, C. Retrieval of the boundary layer height from active and passive remote sensors. Comparison with a NWP model. Acta Geophys. 2014, 62, 276-289. [CrossRef]

36. Beck, C.; Jacobeit, J.; Jones, P.D. Frequency and within-type variations of large-scale circulation types and their effects on low-frequency climate variability in Central Europe since 1780. Int. J. Climatol. 2007, 27, 473-491. [CrossRef]

37. Tveito, O.E.; Huth, R. Circulation-type classifications in Europe: Results of the COST 733 Action. Int. J. Climatol. 2016, 36, 2671-2672. [CrossRef]

38. Philipp, A.; Beck, C.; Huth, R.; Jacobeit, J. Development and comparison of circulation type classifications using the COST 733 dataset and software. Int. J. Climatol. 2016, 36, 2673-2691. [CrossRef] 
39. Dee, D.P.; Uppala, S.M.; Simmons, A.J.; Berrisford, P.; Poli, P.; Kobayashi, S.; Andrae, U.; Balmaseda, M.A.; Balsamo, G.; Bauer, P.; et al. The ERA-Interim reanalysis: Configuration and performance of the data assimilation system. Q. J. Roy. Meteor. Soc. 2011, 137, 553-597. [CrossRef]

40. Muller, D.; Mattis, I.; Ansmann, A.; Wandinger, U.; Ritter, C.; Kaiser, D. Multiwavelength Raman lidar observations of particle growth during long-range transport of forest-fire smoke in the free troposphere. Geophys. Res. Lett. 2007, 34, L05803. [CrossRef]

41. Schuster, G.L.; Dubovik, O.; Holben, B.N. Angstrom exponent and bimodal aerosol size distributions. J. Geophys. Res. 2006, 111, D07207. [CrossRef]

42. Cao, N.; Yang, S.; Cao, S.; Yang, S.; Shen, J. Accuracy calculation for lidar ratio and aerosol size distribution by dual-wavelength lidar. Appl. Phys. A 2019, 125, 590. [CrossRef]

43. Chubarova, N.Y.; Poliukhov, A.A.; Gorlova, I.D. Long-term variability of aerosol optical thickness in Eastern Europe over 2001-2014 according to the measurements at the Moscow MSU MO AERONET site with additional cloud and NO2 correction. Atmos. Meas. Tech. 2016, 9, 313-334. [CrossRef]

44. Nicolae, D.; Nemuc, A.; Müller, D.; Talianu, C.; Vasilescu, J.; Belegante, L.; Kolgotin, A. Characterization of fresh and aged biomass burning events using multiwavelength Raman lidar and mass spectrometry. J. Geophys. Res. 2013, 118, 2956-2965. [CrossRef]

45. Galytska, E.; Danylevsky, V.; Hommel, R.; Burrows, J.P. Increased aerosol content in the atmosphere over Ukraine during summer 2010. Atmos. Meas. Tech. 2018, 11, 2101-2118. [CrossRef]

46. Cachorro, V.E.; Toledano, C.; Prats, N.; Sorribas, M.; Mogo, S.; Berjón, A.; Torres, B.; Rodrigo, R.; de la Rosa, J.; DeFrutos, A.M. The strongest desert dust intrusion mixed with smoke over the Iberian Peninsula registered with Sun photometry. J. Geophys. Res. 2008, 113, D14S04. [CrossRef]

47. Ortiz-Amezcua, P.; Guerrero-Rascado, J.L.; Granados-Muñoz, M.J.; Benavent-Oltra, J.A.; Böckmann, C.; Samaras, S.; Stachlewska, I.S.; Janicka, Ł.; Baars, H.; Bohlmann, S.; et al. Microphysical characterization of long-range transported biomass burning particles from North America at three EARLINET stations. Atmos. Chem. Phys. 2017, 17, 5931-5946. [CrossRef]

48. Suchara, I.; Sucharova, J. Distribution of Sulphur and Heavy Metals in Forest Floor Humus of the Czech Republic. Water. Air Soil Pollut. 2002, 136, 289-316. [CrossRef]

49. Ancellet, G.; Pelon, J.; Totems, J.; Chazette, P.; Bazureau, A.; Sicard, M.; Di Iorio, T.; Dulac, F.; Mallet, M. Long-range transport and mixing of aerosol sources during the 2013 North American biomass burning episode: Analysis of multiple lidar observations in the western Mediterranean basin. Atmos. Chem. Phys. 2016, 16, 4725-4742. [CrossRef]

50. Chazette, P.; Totems, J.; Ancellet, G.; Pelon, J.; Sicard, M. Temporal consistency of lidar observations during aerosol transport events in the framework of the ChArMEx/ADRIMED campaign at Minorca in June 2013. Atmos. Chem. Phys. 2016, 16, 2863-2875. [CrossRef]

51. Brocchi, V.; Krysztofiak, G.; Catoire, V.; Guth, J.; Marécal, V.; Zbinden, R.; El Amraoui, L.; Dulac, F.; Ricaud, P. Intercontinental transport of biomass burning pollutants over the Mediterranean Basin during the summer 2014 ChArMEx-GLAM airborne campaign. Atmos. Chem. Phys. 2018, 18, 6887-6906. [CrossRef]

52. Janika, L.; Stachlewska, I.S.; Veselovskii, I.; Baars, H. Temporal variations in optical and microphysical properties of mineral dust and biomass burning aerosol derived from daytime Raman lidar observations over Warsaw, Poland. Atmos. Environ. 2017, 169, 162-174. [CrossRef]

53. Janicka, L.; Stachlewska, I.S. Properties of biomass burning aerosol mixtures derived at fine temporal and spatial scales from Raman lidar measurements: Part I optical properties. Atmos. Chem. Phys. Discuss. 2019. in review. [CrossRef]

54. Martinsson, J.; Monteil, G.; Sporre, M.K.; Kaldal Hansen, A.M.; Kristensson, A.; Eriksson Stenström, K.; Swietlicki, E.; Glasius, M. Exploring sources of biogenic secondary organic aerosol compounds using chemical analysis and the FLEXPART model. Atmos. Chem. Phys. 2017, 17, 11025-11040. [CrossRef]

55. Vaughan, G.; Draude, A.P.; Ricketts, H.M.A.; Schultz, D.M.; Adam, M.; Sugier, J.; Wareing, D.P. Transport of Canadian forest fire smoke over the UK as observed by lidar. Atmos. Chem. Phys. 2018, 18, 11375-11388. [CrossRef]

56. Hu, Q.; Goloub, P.; Veselovskii, I.; Bravo-Aranda, J.-A.; Popovici, I.E.; Podvin, T.; Haeffelin, M.; Lopatin, A.; Dubovik, O.; Pietras, C.; et al. Long-range-transported Canadian smoke plumes in the lower stratosphere over northern France. Atmos. Chem. Phys. 2019, 19, 1173-1193. 
57. Talianu, C.; Seibert, P. Analysis of sulfate aerosols over Austria: A case study. Atmos. Chem. Phys. 2019, 19, 6235-6250. [CrossRef]

58. Vieno, M.; Heal, M.R.; Twigg, M.M.; MacKenzie, I.A.; Braban, C.F.; Lingard, J.J.N.; Ritchie, S.; Beck, R.C.; Moring, A.; Ots, R.; et al. The UK particulate matter air pollution episode of March-April 2014: More than Saharan dust. Environ. Res. Lett. 2016, 11, 044004. [CrossRef]

59. Nunes, L.; Álvarez-González, J.; Alberdi, I.; Silva, V.; Rocha, V.; Castro Rego, F. Analysis of the occurrence of wildfires in the Iberian Peninsula based on harmonised data from national forest inventories. Ann. For. Sci. 2019, 76, 27. [CrossRef]

60. Cachorro, V.E.; Burgos, M.A.; Mateos, D.; Toledano, C.; Bennouna, Y.; Torres, B.; de Frutos, Á.M.; Herguedas, Á. Inventory of African desert dust events in the north-central Iberian Peninsula in 2003-2014 based on sun-photometer-AERONET and particulate-mass-EMEP data. Atmos. Chem. Phys. 2016, 16, 8227-8248. [CrossRef]

61. Granados-Muñoz, M.J.; Navas-Guzmán, F.; Guerrero-Rascado, J.L.; Bravo-Aranda, J.A.; Binietoglou, I.; Pereira, S.N.; Basart, S.; Baldasano, J.M.; Belegante, L.; Chaikovsky, A.; et al. Profiling of aerosol microphysical properties at several EARLINET/AERONET sites during the July 2012 ChArMEx/EMEP campaign. Atmos. Chem. Phys. 2016, 16, 7043-7066. [CrossRef]

62. Mortier, A.; Goloub, P.; Podvin, T.; Deroo, C.; Chaikovsky, A.; Ajtai, N.; Blarel, L.; Tanre, D.; Derimian, Y. Detection and characterization of volcanic ash plumes over Lille during the Eyjafjallajökull eruption. Atmos. Chem. Phys. 2013, 13, 3705-3720. [CrossRef]

63. Turco, M.; von Hardenberg, J.; AghaKouchak, A.; Llasat, M.C.; Provenzale, A.; Trigo, R. On the key role of droughts in the dynamics of summer fires in Mediterranean Europe. Sci. Rep. 2017, 7, 81. [CrossRef] [PubMed]

64. Hanel, M.; Rakovec, O.; Markonis, Y.; Máca, P.; Samaniego, L.; Kyselý, J.; Kumar, R. Revisiting the recent European droughts from a long-term perspective. Sci. Rep. 2018, 8, 9499. [CrossRef] [PubMed]

65. Russo, S.; Sillmann, J.; Fischer, E. Top ten European heatwaves since 1950 and their occurrence in the coming decades. Environ. Res. Lett. 2015, 10, 124003. [CrossRef]

66. Ionita, M.; Tallaksen, L.M.; Kingston, D.G.; Stagge, J.H.; Laaha, G.; van Lanen, H.A.J.; Scholz, P.; Chelcea, S.M.; Haslinger, K. The European 2015 drought from a climatological perspective. Hydrol. Earth Syst. Sci. 2017, 21, 1397-1419. [CrossRef]

67. DIRECTIVE (EU) 2016/2284 OF THE EUROPEAN PARLIAMENT AND OF THE COUNCIL on the reduction of national emissions of certain atmospheric pollutants, amending Directive 2003/35/EC and repealing Directive 2001/81/EC. Available online: https:/eur-lex.europa.eu/legal-content/EN/ALL/?uri=CELEX\%3A32016L2284 (accessed on 9 August 2019).

68. DIRECTIVE (EU) 2015/2193 OF THE EUROPEAN PARLIAMENT AND OF THE COUNCIL on the limitation of emissions of certain pollutants into the air from medium combustion plants. Available online: https: //eur-lex.europa.eu/legal-content/EN/TXT/?uri=CELEX\%3A32015L2193 (accessed on 9 August 2019).

69. Provençal, S.; Pavel Kishcha, P.; da Silva, A.M.; Elhacham, E.; Alpert, P. AOD distributions and trends of major aerosol species over a selection of the world's most populated cities based on the 1st Version of NASA's MERRA Aerosol Reanalysis. Urban. Clim. 2017, 20, 168-191. [CrossRef]

70. Markowicz, K.; Pakszys, P.; Ritter, C.; Zielinski, T.; Udisti, R.; Cappelletti, D.; Mazzola, M.; Shiobara, M.; Lynch, P.; Zawadzka, O.; et al. Impact of North American intense fires on aerosol optical properties measured over the European Arctic in July 2015. J. Geophys. Res. Atmos. 2016, 121, 14487-14512. [CrossRef]

(C) 2019 by the authors. Licensee MDPI, Basel, Switzerland. This article is an open access article distributed under the terms and conditions of the Creative Commons Attribution (CC BY) license (http://creativecommons.org/licenses/by/4.0/). 